\title{
Bioaccumulation of zinc, lead, cadmium in water hyacinth, hippo grass and papyrus reed as water quality indicator in River Kisat in
}

Kisumu County, Kenya.

\author{
Mareri B. ${ }^{1 *}$, Kitur E. ${ }^{1}$, Obade P. ${ }^{1}$ \\ ${ }^{1 *}, 1,1$ Department of Environmental Sciences and Education, Kenyatta University, \\ P.O Box 43844-0100, Nairobi, Kenya. \\ ${ }^{1 *}$ Corresponding author's email: brenda.mareri@gmail.com
}

Received: 10 February 2021 / Accepted: 22 May 2021 / Published online: 30th June 2021

\section{ABSTRACT}

River Kisat in Kenya is increasingly being polluted serving as a sink for waste receiving effluent from sewerage, industrial waste and agricultural pesticide residues leading to heavy metal contamination. This has led to the contamination of the aquatic ecosystem and water used by communities for consumption and farming. Little information is available on the bio-indicative aspects of water quality using bioaccumulation factor by macrophytes. This study aimed at determining concentrations of $\mathrm{Zn}, \mathrm{Pb}$ and $\mathrm{Cd}$ in water, Eichhornia crassipes (water hyacinth), Vossia cuspidata (hippo grass), Cyperus papyrus (papyrus reed) and bioaccumulation factors (BAF) in River Kisat, Kisumu County. This was determined following laboratory standard procedures using Atomic Absorption Spectrophotometer (AAS). Results showed mean concentrations (mg/L) of Cd (Below detectable limit), $\mathrm{Zn}$ $(0.2-0.15)$ and $\mathrm{Pb}(0.03-0.03)$ in water. Mean values were within allowable WHO drinking water limits except for $\mathrm{Pb}$ which was above acceptable limits. $\mathrm{Zn}$ recorded highest accumulated levels in E. crassipes $(72.43 \mathrm{mg} / \mathrm{L})$, C. papyrus $(70.13 \mathrm{mg} / \mathrm{L})$ and $V$. cuspidate $(71.03 \mathrm{mg} / \mathrm{L})$. E. crassipes was observed to bioaccumulate the highest concentration of the heavy metals with $C$. papyrus bioaccumulating the lowest (E. crassipes $>V$. cuspidata $>C$. papyrus). Pearson matrix correlation analysis showed positive significant correlations $(\mathrm{r}=0.621 ; \mathrm{p}=0.027)$ between $\mathrm{Zn}$ and $\mathrm{Pb}$ in water and the macrophytes which reflected a common source of pollution and indication of accumulation. BAF recorded for all macrophytes ranged from 2.45 to 6.85 , above value of 1 , indicating significant bioaccumulation for $\mathrm{Zn}$ and $\mathrm{Pb}$. The findings from this study showed
\end{abstract}

higher concentrations of $\mathrm{Zn}$ and $\mathrm{Pb}$ in the macrophytes in comparison to the water in River Kisat with BAF values $>1$ indicating bioaccumulation which represented poor water quality. The study recommends local authorities employ monitoring processes with incorporation of $\mathrm{BAF}$ as a water quality indicator where low metal concentrations in water are recorded, introduce penalties for polluters and sensitize local inhabitants on detrimental health effects of heavy metal and avoid use of River Kisat water for agricultural activities.

Keywords: Bioaccumulation, macrophytes, water quality, heavy metals, River Kisat.

\section{INTRODUCTION}

Direct and indirect discharge of pollutants into water bodies with limited treatment to remove pollutants leads to water pollution. Pollution of water bodies directly affects the organisms living in these water bodies and affects all natural biological communities. Toxic substances such as heavy metals are pollutants that accumulate in the ecosystem easily (An et al., 2015). Anthropogenic activities for example pesticide production, processing of metals, mining, electroplating and energy generation geothermally can lead to global heavy metal contamination (Peligro et al., 2016). Heavy metals exist in wastewater in different chemical forms hence their removal is difficult. Their nonbiodegradable nature allows them to pass through various trophic levels and hence persist and accumulate in biota (Gall et al., 2015). 
In Africa, Asia and Europe sources of metals are excessive fertilizer and pesticide use, waste, weathering rocks which contribute almost $50 \%$ total causes of pollution in aquatic systems (Qiaoqiao et al., 2020). Large river basins also face threats of pollution. Surface water heavy metal pollution has evolved from single to mixed pollution. City sewerage systems and factory untreated waste add large amounts of pollutants into river systems that serve local populations (Sinha \& Loganathan, 2015). Human exposure to heavy metals occurs in various ways through food, water, air pollution or occupational exposure. Iron and manganese are examples of essential metals for biochemical and physiological body activities but elevated levels cause negative health effects. Heavy metals are toxic even at low levels. Long term intake of unsafe levels of heavy metals through foods may result in disruption of many biological and biochemical processes in humans. Consumption of water or food with high levels of zinc can lead to extensive health problems as stomach inflammations, skin cancers and anaemia. Lead and cadmium have been shown to affect reproductive systems, hepatic, endocrine, immune and gastrointestinal systems in both adults and children leading to lifelong illnesses or death (Jamshaid et al., 2018).

Macrophytes act as key accumulators of heavy metals by passively and absorbing actively therefore playing a key aspect of the wetland geochemistry (Vodyanitskii \& Shoba, 2015). Some species of macrophytes can accumulate heavy metals to exceed the content in their ecosystem and are considered hyper accumulators. These species therefore can be used as indicators of environmental hazards and indicate the bioaccumulation potential of the species which in turn can evaluate persistence and toxic nature of metals (Singh et al., 2017). Trace elements in their ionic form can enter food chains in the ecosystem due to their persistence in nature. This in turn leads to their accumulation and contamination of biotic factors. Bioaccumulation factor determines the quotient of a metal in a plant to its initial content in the environment, specifically in water.

Monitoring of metal pollution has focused on metal concentrations in water, biota and sediments but dependence on water analysis is not a fully accurate method to identify metal inputs in aquatic systems (Turkmen et al., 2006). Determination of metal concentrations in aquatic organisms and their bioaccumulation factor is key in evaluating quality of water systems (Bastami et al., 2015). Macrophytes can be used as indicators of quality in the aquatic environment through by their uptake of heavy metals from the environment even at low concentrations (Matache et al., 2013).

Agricultural land is under heightened pressure in Kenya and settlements by inhabitants has led to water catchment area destruction. There are many human activities documented that have impacted the state of Lake Victoria catchments such as Nyando, Nzoia, Yala, and SonduMiriu (Mutuku et al., 2014; Ongeri et al., 2009). River Kisat receives wastewater, industrial and municipal wastes from anthropogenic activities from Kisumu city. The river flows into Lake Victoria basin through areas that have similar geological characteristics. The rainfall received in the area is moderate and most activities carried out include small scale maize and sugarcane farming as well as fishing. The dominant macrophyte species in River Kisat are Eichhornia crassipes, Vossia cuspidata and Cyperus papyrus. The river is an important source of water for consumption and for irrigation of agricultural activities. Human activities and natural or geological disturbances such as soil erosion, siltation, industrial effluents and rainfall can affect the deposits of organic and inorganic load in River Kisat aquatic ecosystem (Lalah et al., 2008). The river is polluted by effluent from the municipality, discharge from Kisat Wastewater Treatment Plant (KWTP), untreated waste from Nyalenda Waste Stabilization Ponds (NWSP), industrial effluent discharge from cosmetic industries in the locality, solid waste dumped from Obunga slums settlement, waste oil from informal car services garages and disposal of used molasses from informal alcohol brewing sites (Chamula et al., 2013).

The main challenge facing River Kisat is the extensive pollution of the river with heavy metals which affects the biota such as the macrophytes and poses a major health risk to the inhabitants of the area and their livelihood. Bioaccumulation status of the dominant macrophytes in River Kisat is unknown and has not been studied which is a threat to biodiversity and to communities consuming crops planted using contaminated water and using macrophytes as livestock feed. Aquatic vegetation in the Lake Victoria region is harvested for many purposes and many parts of the vegetation such as Cyperus papyrus plant can be utilized for fodder for animals. Besides $C$. papyrus, other wetland plant species such as Phragmites spp., Eichhornia crassipes are harvested for consumption by locals (herbs and medicinal plants) as well as fodder for animals kept in the homestead (Van Dam \& Kipkemboi, 2016). Bioaccumulation factor can be utilized to assess the effects of heavy metal pollution on biodiversity and more so assess the extent of water quality in River Kisat providing time integrated information on metal presence.

The research problem addressed in this study is the environmental impact that heavy metal pollution has on the biota and potential social impact in the region in River Kisat. The aim of this study was to determine the levels of heavy metals in River Kisat water and in macrophytes and 
to establish the bioaccumulation factors between water and macrophytes as an indicator of water quality and heavy metal pollution.

\section{MATERIALS AND METHODOLOGY}

\section{Study area}

River Kisat is situated in Kisumu Bay with coordinates of latitudes $0^{\circ} 18^{\prime} \mathrm{S}$ to $0^{\circ} 04^{\prime} \mathrm{N}$ and longitudes $34^{\circ} 43^{\prime} \mathrm{E}$ to $35^{\circ} 30^{\prime} \mathrm{E}$ (Figure 1). Located near the river source was sampling site $\mathrm{K} 1,3.5 \mathrm{~km}$ from the river mouth located at the Kisat bridge characterized by disposal of waste oil from informal car-services garages and used molasses from local brewing. Site K2 was located $1 \mathrm{~km}$ from K1, $2.5 \mathrm{~km}$ from the river mouth, receiving effluent from the Kisat wastewater sewage and treatment plant area located in an Industrial area. Site K3 was located $1 \mathrm{~km}$ away from K2 and $1.5 \mathrm{~km}$ away from the river mouth in the Obunga slums with solid wastes dumped from informal settlements and various small cosmetic industries dumping waste into the River. K4 was located 500 metres away from the outlet of River Kisat into Lake Victoria and $1 \mathrm{~km}$ away from K3 where local inhabitants practice agricultural activities with heavy point source pollution from agricultural activities due to pesticide and fertilizer use and run off.

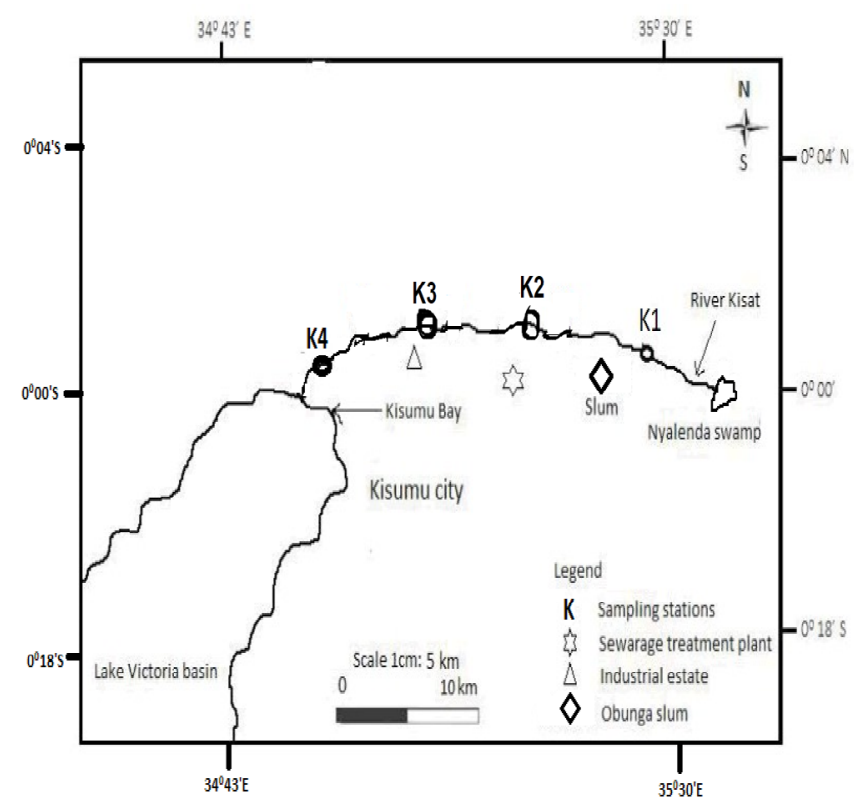

Figure 1: Location of River Kisat in Lake Victoria Basin and selected sampling sites.

\section{Water and macrophyte sample collection}

Water sampling was done according to the procedures described by Ndimele and Johnson (2012). Water samples from all four sampling sites were collected at a depth of approximately 0.3 meters below the water surface and approximately 1.5 metres away from the riverbank at 3 different points on both sides of the riverbank using a 2-litre plastic Van Dorn water sampler and transferred into $500 \mathrm{ml}$ polypropylene bottles. Three droplets of Nitric acid $\left(\mathrm{HNO}_{3}\right)$ were added to the samples to reduce $\mathrm{pH}$ to $<2$ to ensure no precipitation and adsorption of metal ions to the polypropylene walls of the sample bottles. Samples were stored in a cool box at $4^{0} \mathrm{C}$ in order to halt the chemical and biological activities from occurring post sampling prior to analysis.

Three plant species were selected namely Eichhornia crassipes, Vossia cuspidata and Cyperus papyrus due to their dominance in the River Kisat ecosystem. Three composite samples of each of the macrophytes from the above-ground section (culms and stems) of C. papyrus and V. cuspidata and below ground section (submerged stolon sections) of $E$. crassipes were taken from each site. Plants were handpicked wearing nitrile gloves and were thoroughly washed at the sampling site using the sample water until appeared to be clean. Each plant sample was wrapped in foil to preserve the sample and placed in plastic airtight bags. Bags were sealed, labelled and stored at $4^{\circ} \mathrm{C}$ to wait for analysis.

\section{Digestion of water samples}

Digestion of water samples was done using concentrated Nitric acid $\left(\mathrm{HNO}_{3}\right)$ and Sulphuric $\left(\mathrm{H}_{2} \mathrm{SO}_{4}\right)$ acid. Concentrated nitric acid $\left(\mathrm{HNO}_{3}\right)(10 \mathrm{ml})$ and concentrated Sulphuric acid $\left(\mathrm{H}_{2} \mathrm{SO}_{4}\right)(5 \mathrm{ml})$ was added to $50 \mathrm{ml}$ of the water sample, heated to boil in a block digester until turbidity and color was clear. This was allowed to cool and the digested material was sieved through filter paper (0.45um, whatman paper) into a flask and distilled water used to make the digest to the $100 \mathrm{ml}$ mark. Final filtrate was put in $100 \mathrm{ml}$ plastic bottles for heavy metals analysis. Analysis was done using Atomic Absorption Spectrometer (Spectra AA-10 model). The blank solutions were aspirated along with the digested samples.

\section{Digestion of macrophytes samples}

Macrophyte samples were placed in an oven and dried for 48 hours at $90^{\circ} \mathrm{C}$ to constant weight. Dried sample was crushed using pestle and mortar. Homogenized composite powder sample for each sample group was prepared by grinding crushed sample using stainless steel grinder. Digestion of the sample was done by adding $10 \mathrm{ml}$ of concentrated $\mathrm{HNO}_{3}$ to $2 \mathrm{~g}$ of the finely ground homogenized powder, heated at $80^{\circ} \mathrm{C}$ for 6 hours until a transparent color appeared of the sample. Digested mixture was evaporated to dryness and residue dissolved in $10 \mathrm{ml}$ of $1 \mathrm{~N} \mathrm{HNO}_{3}$. This was filled to the $100 \mathrm{ml}$ with double deionized water in a volumetric flask and passed through a 0.45 um filter paper and transferred to $100 \mathrm{ml}$ polypropylene containers for metal analysis using the AAS. 


\section{Data analysis}

Data was subjected to ANOVA. Significance was accepted at $\mathrm{p} \leq 0.05$. Post-hoc Tukey's HSD test (HSD) test was used to separate the means. Pearson's correlation analysis established relationship between mean concentrations in waster and plants. The bioaccumulation factor (BAF) was calculated as follows:

$$
\mathrm{BAF}=\frac{\text { Metal content in plant }(\mathrm{mg} / \mathrm{L})}{\text { Metal content in water }(\mathrm{mg} / \mathrm{L})}
$$

\section{RESULTS AND DISCUSSION}

\section{$\mathrm{Zn}, \mathrm{Pb}, \mathrm{Cd}$ concentrations in water}

The mean $\mathrm{Zn}$ concentration levels are presented in Table 1. Zn concentration levels recorded were within the WHO set limits for water for human consumption. The elevated levels of $\mathrm{Zn}$ at K1, river source could be attributed to sewage and industrial effluent from the surrounding area (Table 1). This could be due to $\mathrm{Zn}^{2+}$ ions being more bioavailable in suitable conditions of $\mathrm{pH}$ and temperature. The introduction of Zinc in water can be done naturally through mineral erosion from soil and rocks or through anthropogenic activities such as manufacturing of steel products, fertilizer leachate, effluents from the municipal and the destruction of waste materials through burning (Tomno et al., 2020). In Dar es Salaam, a study conducted on River Msimbazi polluted by leakage of effluents from waste dumps, abattoirs, and domestic wastewater from septic tanks in Temeke municipality recorded Zinc levels of $0.99-1.26 \mathrm{mg} / \mathrm{L}$ which were slightly higher than what was recorded in this study (Kacholi et al., 2018).

The mean $\mathrm{Pb}$ concentration levels in water are presented in Table 1. Pb concentration levels were above the WHO set limits for drinking water except for site K3 which was within $\mathrm{WHO}$ limits. The levels of $\mathrm{Pb}$ recorded in River Kisat could be attributed to the presence of various industries dealing in cosmetics and motor vehicle repairs that drained effluent directly into the river before treatment. Sources of $\mathrm{Pb}$ pollution include industrial effluents, pesticides, fertilizers, sewage sludge and the mining or smelting of $\mathrm{Pb}$ core which has severe effects on plant and animal life and functions (Malar et al., 2016). A study on the Yacuambi River in Ecuador by Villa-Achupallas et al. (2018) was found polluted by gold metal mining activities and recorded mean $\mathrm{Pb}$ levels of $0.113 \mathrm{mg} / \mathrm{L}$ which were comparable to levels recorded in this study.

In this study $\mathrm{Cd}$ levels were below the detection limit (Table 1) which indicates that there is minimal cadmium pollution in the river and possibly in the surrounding localities. Cadmium can be introduced into the aquatic water systems as a result of anthropogenic activities for example the application of fertilizer, mining or smelting of metal ores and also from natural occurrences such as rock weathering. A study by Njuguna et al. (2017) on Cd concentrations in Nairobi River polluted by human and industrial waste from Korogocho slums recorded mean values of $0.0043 \mathrm{mg} / \mathrm{L}$ which were low levels comparable to the below detectable limits recorded in this study.

\section{Concentrations of $\mathrm{Pb}, \mathrm{Zn}, \mathrm{Cd}$ in macrophytes}

The mean $\mathrm{Zn}, \mathrm{Pb}$ and $\mathrm{Cd}$ concentration levels in $E$. crassipes are presented in Table 2 . From this study the results showed that Eichhornia crassipes is a good bioaccumulator of $\mathrm{Zn}$ and $\mathrm{Pb}$. E. crassipes a free floating macrophytes was observed to bioaccumulate the highest concentration of the three heavy metals (Table 2). E. crassipes has a greater capacity to remove metals from their environment as these species grow in abundance (Radu et al., 2017). Aquatic macrophytes of free floating nature such as water hyacinth (Eichhornia crassipes) has high potential and capability to remove heavy metals from their ecosystem. They actively transport heavy metals through their root system to the stems and leaves (Gunathilakae et al., 2018). Mean varied levels of metals recorded from Cyperus papyrus are summarized in Table 2. From the results $C$. papyrus accumulated high concentration of Zinc at the river source which could be attributed to untreated wastewater released into River Kisat (Table 2). Cyperus papyrus has been used in the phytoremediation of metals in water systems and has exhibited capacity in the retention of heavy metals such as $\mathrm{Cu}, \mathrm{Pb}, \mathrm{Zn}$ and Iron (Mbemba et al., 2019). The mean $\mathrm{Zn}, \mathrm{Pb}$ and $\mathrm{Cd}$ concentration levels in V. cuspidata for all the sampling sites are presented in Table 2. Cd levels were below detectable limit. The concentration of $\mathrm{Zn}$ and $\mathrm{Pb}$ in $V$. cuspidata is an indicator that the plant can bioaccumulate heavy metals (Table 2). The bioaccumulation of heavy metals in most emergent plants such as $V$. cuspidata is restricted due to the upward transport mechanism which is the movement of compounds towards the tips of the plant extremities hence the minimal levels of metals (Outa et al., 2020).

The upward or acropetal mechanism of emergent plants to transport compounds to plant extremities such as stems and leaves restricts movement of compounds which provides insight into the subsided levels of heavy metals in the leaves and stems of $V$. cuspidata and $C$. papyrus in comparison to E. crassipes (Sayer et al., 2018). Another study done by Ndeda and Manohar (2014) in Nairobi Dam showed that free floating macrophytes had greater accumulation ability values of $\mathrm{Cu}, \mathrm{Cd}$ and $\mathrm{Pb}$ compared to emergent species. This concludes that free floating macrophytes have better ability to bioaccumulate heavy metals than emergent macrophytes. 


\begin{tabular}{|c|c|c|c|c|c|}
\hline $\begin{array}{c}\text { Element/Sample } \\
\text { Site }\end{array}$ & K1 & K2 & K3 & K4 & $\begin{array}{c}\text { WHO } \\
\text { Standards } \\
3^{\mathrm{RD}} \text { Edition } \\
(\mathrm{mg} / \mathrm{L})\end{array}$ \\
\hline $\mathrm{Zn}(\mathrm{mg} / \mathrm{L})$ & $0.22 \pm 0.04^{\mathrm{a}}$ & $0.12 \pm 0.07^{\mathrm{a}}$ & $0.13 \pm 0.13^{a}$ & $0.15 \pm 0.07^{\mathrm{a}}$ & \multirow[t]{2}{*}{ 1 } \\
\hline Range & $0.22-0.22$ & $0.11-0.13$ & $0.15-0.13$ & $0.16-0.14$ & \\
\hline $\mathrm{Cd}(\mathrm{mg} / \mathrm{L})$ & ND & ND & ND & ND & 0.003 \\
\hline $\mathrm{Pb}(\mathrm{mg} / \mathrm{L})$ & $0.03 \pm 0.01^{\mathrm{a}}$ & $0.02_{-} \pm 0.04^{\mathrm{a}}$ & $0.01 \pm 0.01^{\mathrm{a}}$ & $0.03 \pm 0.05^{\mathrm{a}}$ & \multirow[b]{2}{*}{0.01} \\
\hline Range & $0.02-0.02$ & $0.02-0.01$ & $0.01-0.01$ & $0.03-0.01$ & \\
\hline
\end{tabular}

Note: Different letter superscripts $=$ significant difference at $\mathrm{p}<0.05 . \mathrm{ND}=$ below detectable limit

Table 2: Mean values of $\mathrm{Zn}, \mathrm{Pb}$ and $\mathrm{Cd}(\mathrm{mg} / \mathrm{L})$ in macrophytes

\begin{tabular}{|c|c|c|c|c|c|}
\hline Plant Species & Sample Site & K1 & $\mathbf{K} 2$ & K3 & K4 \\
\hline Vossia & Zinc(mg/L) & $71.03 \pm 0.26$ & $78.95 \pm 0.05$ & $34.79 \pm 0.50$ & $31.50 \pm 0.40$ \\
\hline \multirow[t]{3}{*}{ cuspidata } & Range & $70.03-71.04$ & $54.34-79.04$ & $24.12-35.92$ & $24.56-33.72$ \\
\hline & Lead(mg/L) & $11.01 \pm 0.14$ & $6.23 \pm 0.07$ & $2.94 \pm 0.23$ & $3.74 \pm 0.14$ \\
\hline & $\begin{array}{c}\text { Range } \\
\text { Cadmium(mg/L) }\end{array}$ & $9.43-12.56$ & $5.34-6.78$ & $1.92-3.66$ & $3.55-4.12$ \\
\hline Cyperus & Zinc(mg/L) & $70.13 \pm 0.40$ & $79.10 \pm 0.05$ & $32.01 \pm 0.50$ & $30.95 \pm 0.26$ \\
\hline \multirow[t]{4}{*}{ papyrus } & Range & $70.01-70.14$ & $78.23-79.11$ & $30.33-32.04$ & $30.85-30.95$ \\
\hline & Lead(mg/L) & $10.45 \pm 0.07$ & $6.18 \pm 0.23$ & $3.21 \pm 0.07$ & $3.64 \pm 0.14$ \\
\hline & Range & $10.33-10.45$ & $6.14-6.19$ & $3.19-3.22$ & $3.62-3.64$ \\
\hline & $\operatorname{Cadmium}(\mathrm{mg} / \mathrm{L})$ & ND & ND & ND & ND \\
\hline \multirow{5}{*}{$\begin{array}{c}\text { Eichhornia } \\
\text { crassipes }\end{array}$} & Zinc(mg/L) & $72.43 \pm 0.40$ & $79.07 \pm 0.05$ & $34.63 \pm 0.51$ & $31.51 \pm 0.26$ \\
\hline & Range & $71.40-72.33$ & $78.03-79.15$ & $33.41-34.65$ & $30.15-31.50$ \\
\hline & Lead(mg/L) & $11.04 \pm 0.23$ & $6.33 \pm 0.07$ & $3.54 \pm 0.14$ & $3.78 \pm 0.07$ \\
\hline & Range & $11.01-11.05$ & $6.22-6.34$ & $3.30-3.54$ & $3.62-3.78$ \\
\hline & $\operatorname{Cadmium}(\mathrm{mg} / \mathrm{L})$ & ND & ND & ND & ND \\
\hline
\end{tabular}

Note: ${ }^{*}=$ significant difference at $\mathrm{p}<0.05, \mathrm{ND}=$ below detectable limit

\section{Relationships between water and macrophytes metals concentrations and BAF}

Pearson correlation was determined to measure the relation and linear dependence between concentration of metals in water and macrophytes. The concentration of $\mathrm{Zn}$ and $\mathrm{Pb}$ in $E$. crassipes showed positive significant correlation with $\mathrm{Zn}$ and $\mathrm{Pb}$ in water $(\mathrm{r}=0.621 ; \mathrm{p}=0.027)$ and $(\mathrm{r}=0.358$; $\mathrm{p}=0.023$ ) respectively (Table 3 ). The concentration of $\mathrm{Zn}, \mathrm{Pb}$ in $C$. papyrus showed positive significant correlation with $\mathrm{Zn}$ and $\mathrm{Pb}$ levels in water $(\mathrm{r}=0.592 ; \mathrm{p}$ $=0.027),(\mathrm{r}=0.456 ; \mathrm{p}=0.015)$ respectively (Table 3). $\mathrm{Zn}$ and $\mathrm{Pb}$ concentrations in $V$. cuspidata showed weak positive correlations with $\mathrm{Zn}$ and $\mathrm{Pb}$ in water $(\mathrm{r}=0.153$; $\mathrm{p}$ $=0.033),(r=0.248 ; p=0.036)$ (Table 3).
Table 3: $r$ values of correlation between water and macrophytes in River Kisat

\begin{tabular}{ccc}
\hline & Zn-Water & Pb- Water \\
\hline $\mathrm{Zn}-$ E.crassipes &. $\mathbf{6 2 1 *}$ & .384 \\
$\mathrm{~Pb}-$ E.crassipes & .347 &. $\mathbf{3 5 8 *}$ \\
$\mathrm{Zn}$-C.papyrus & $\mathbf{. 5 9 2 *}$ & .006 \\
$\mathrm{~Pb}-$ C.papyrus & -.057 &. $\mathbf{4 5 6 *}$ \\
$\mathrm{Zn}-$ V.cuspidata &. $\mathbf{1 5 3 *}$ & -.293 \\
$\mathrm{~Pb}-$ V.cuspidata & -.059 &. $\mathbf{2 4 8 *}$ \\
$\mathrm{Zn}$-Water & .194 & .265 \\
$\mathrm{~Pb}-$ Water & .146 & .299
\end{tabular}

Note: ${ }^{*}=$ Correlation significance 
The noted significant correlations among the heavy metals reflected a common source of occurrence and an indication of similar accumulation pathways for subsequent accumulation in macrophytes species.

Bioaccumulation factor was calculated to determine the extent of heavy metal bioaccumulation by the macrophytes and indicate the quality of water. The bioaccumulation factor (BAF) of heavy metals in the macrophyte species and River Kisat water are presented in Table 4. The results indicated no significant difference in the BAF values between the different sampling sites ( $p=0.619$; $\mathrm{df}=$ 36) (Table 4). The 3 macrophyte species in River Kisat recorded $\mathrm{BAF}$ values $>1$ for $\mathrm{Pb}$ and $\mathrm{Zn}$ (Table 4). The high $\mathrm{BAF}$ values for $\mathrm{Pb}$ and $\mathrm{Zn}$ indicate that all 3 plant species were able to bioaccumulate $\mathrm{Pb}$ and $\mathrm{Zn}$ from River Kisat (Table 4). The ability and efficiency of plants to accumulate heavy metals in their plant tissues to levels higher than the surrounding environment exceeding the amounts of heavy metals in their aquatic ecosystem indicates extensive heavy metal pollution (Singh et al., 2017). These BAF values were evidence that $\mathrm{Zn}$ and $\mathrm{Pb}$ were bioaccumulated in the macrophytes and River Kisat water was contaminated with high enough levels of $\mathrm{Pb}$ and Zn to lead to bioaccumulation.

Table 4: Bioaccumulation Factors of heavy metals in E. crassipes, V. cuspidata and C. papyrus from River Kisat

\begin{tabular}{|c|c|c|c|c|}
\hline \multirow[t]{2}{*}{ Macrophytes } & \multicolumn{4}{|c|}{ BAF Values } \\
\hline & Sampling sites & Zinc & Lead & Cadmium \\
\hline \multirow[t]{4}{*}{ Eichhornia crassipes } & $K 1$ & 3.04 & 2.45 & - \\
\hline & $K 2$ & 1.54 & 3.49 & - \\
\hline & K3 & 3.65 & 3.56 & - \\
\hline & K4 & 4.76 & 6.79 & - \\
\hline \multirow[t]{4}{*}{ Cyperus papyrus } & K1 & 3.14 & 2.59 & - \\
\hline & $K 2$ & 1.54 & 3.58 & - \\
\hline & K3 & 3.95 & 3.93 & - \\
\hline & K4 & 4.84 & 7.04 & - \\
\hline \multirow[t]{4}{*}{ Vossia cuspidata } & K1 & 3.10 & 2.46 & - \\
\hline & $K 2$ & 1.54 & 3.55 & - \\
\hline & K3 & 3.64 & 4.29 & - \\
\hline & K4 & 4.76 & 6.85 & - \\
\hline
\end{tabular}

Note: ${ }^{*}=$ significant difference at $\mathrm{p}<0.05$ levels

Therefore, it can be concluded that the key source of contamination of heavy metals by macrophytes species in River Kisat is from the water. The BAF values $>1$ indicate higher concentration of heavy metals in macrophytes in comparison to levels in water was evidence that $\mathrm{Zn}$ and $\mathrm{Pb}$ were bioaccumulated in the macrophytes and that River Kisat water was contaminated with high enough levels of $\mathrm{Pb}$ and $\mathrm{Zn}$ to lead to bioaccumulation which indicated poor water quality.

\section{CONCLUSION}

Mean heavy metal concentrations of $\mathrm{Zn}$ was within recommended WHO levels for water for consumption. Mean concentrations of $\mathrm{Pb}$ were recorded to be higher than WHO limits for water meant for drinking except at one sampling site which recorded levels within WHO set limits $(0.01 \mathrm{mg} / \mathrm{L})$. Cd levels were below detectable limit. Therefore, it was concluded that the amount of heavy metals in River Kisat water is a threat to the water ecosystem. The three macrophytes in River Kisat recorded higher levels of heavy metal concentration than in the water from River Kisat, which indicated bioaccumulated heavy metals. The concentration of $\mathrm{Zn}$ and $\mathrm{Pb}$ in E. crassipes, $C$. papyrus and $V$. cuspidata showed positive significant correlation with $\mathrm{Zn}, \mathrm{Pb}$ in water from River Kisat and BAF values $>1$ was evidence that bioaccumulation factors were indicators of heavy metal pollution. The study shows that the agricultural and industrial activities being conducted along the River Kisat contribute to pollution of the water by heavy metals and subsequently BAF values confirmed accumulation in the macrophytes indicating poor water quality of the river.

\section{ACKNOWLEDGMENT}

We appreciate Kenya Marine and Fisheries Research Institute (KEMFRI) for their assistance and the Kenya Plant Health Inspectorate Services (KEPHIS) for the services rendered on heavy metal analysis of collected samples.

\section{REFERENCES}

An, B., Lee, C. G., Song, M. K., Ryu, J. C., Lee, S., Park, 
S. J., \& Lee, S. H. (2015). Applicability and toxicity evaluation of an adsorbent based on jujube for the removal of toxic heavy metals. React. Funct. Polym, 93, 138-147.

Bastami, K., Neyestani, M., Shemirani, F., Soltani, F., \& Akbari, A. (2015). Heavy metal pollution assessment in relation to sediment properties in the coastal sediments of the southern Caspian Sea. Marine Pollution Bulletin, 92(1-2), 237-243.

Chamula, P., Musungu, I., Jondiko O., Lalah, J., Ongeri, D., Chepkui, R., \& Kiema, F. (2013). The extent of nutrient removal by wastewater treatment plants along the Nyalenda Wigwa Stream and the River Kisat (Kenya). Ecohydrology \& Hydrobiology, 13(4), 236240.

Gall, J. E., Boyd, R. S., \& Rajakaruna, N. (2015). Transfer of heavy metals through terrestrial food webs: A review. Environ. Monit. Assess, 187(4), 201.

Gunathilakae, N., Yapa, N., \& Hettiarachchi, R. (2018). Effect of arbuscular mycorrhizal fungi on the cadmium phytoremediation potential of Eichhornia crassipes. Groundwater for Sustain. Dev, 7(4), 477-482.

Jamshaid, M., Arshad, A. K., \& Kashif, A., \& Saleem, M. (2018). Heavy metal in drinking water its effect on human health and its treatment techniques - a review. Int. J. Biosci, 12(4), 223-240.

Kacholi, D. S., \& Sahu M. (2018). Levels and health risk assessment of heavy metals in soil, water and vegetables of Dar es Salaam, Tanzania. Journal of Chemistry, 2018. https://doi.org/10.1155/2018/1402674.

Lalah, J. O., Ochieng, E. Z., \& Wandiga, S. O. (2008). Sources of heavy metal input into Winam Gulf, Kenya. Bull. Environ. Contam. Toxicol, 81(3), 277-284.

Malar, S., Shivendra Vikram, S., Favas, P. et al. (2016) Lead heavy metal toxicity induced changes on growth and antioxidative enzymes level in water hyacinths Eichhornia crassipes. Bot. Stud, 55(1), 54. doi: 10.1186/ s40529-014-0054-6.

Matache, M. L, Marin. C, Rozylowicz, L., \& Tudorache A. (2013). Plants accumulating heavy metals in the Danube River wetlands. J. Environ. Health. Sci. Eng, 11 (39). https://doi.org/10.1186/2052-336X-11-39.

Mbemba, K. M., Kayath, A. C., Madiélé Mabika, A. B., Aimé Bertrand., Dielé Mouko, G. R., \& Ouamba, J. M. (2019). Phytoremediation of industrial waste leachates by planted filters composed of Phragmites australis (Cav) Trin ex Steud, Typha latifolia L. and Cyperus papyrus L. International Journal of Environment and Climate Change, 9(9), 522-534.

Mutuku, C., Okemo, P., \& Boga, H. (2014). Metal pollutants distribution within Lake Victoria basin and their influence on the native and transient microbial flora. Journal of Agricultural and Biological Science, 9(4).
Ndeda, L. A. \& Manohar, S. (2014). Bio concentration factor and translocation ability of heavy metals within different habitats of hydrophytes in Nairobi Dam, Kenya. Journal of Environmental Science, Toxicology and Food Technology, 8(5), 42-45.

Ndimele, P. E. \& Kumolu-Johnson, C.A. (2012). Some aspects of the Physic Chemistry and heavy metal content of water, sediment and Cynothrissa mento (Regan, 1917) from Badagry Creek, Lagos, Nigeria. Trends in Applied Sciences Research, 7, 724-736.

Njuguna, S. M., Yan. X., Gituru R. W., Wang. Q., \& Wang. J. (2017). Assessment of macrophyte, heavy metal and nutrient concentrations in the water of the Nairobi River, Environ. Monit. Assess, 18 (9).

Ongeri, D. M., Lalah, J. O., Wandiga, S. O., Schramm, K. W., \& Michalke, B. (2009). Levels of toxic metals in multi-sectional samples from Winam Gulf of Lake Victoria. Bulletin of Environmental Contamination and Toxicology, 82(1), 64-69.

Outa, J. O., Kowenje, C., \& Christof Plessl, F. (2020). Distribution of arsenic, silver, cadmium, lead and other trace elements in water, sediment and macrophytes in the Kenyan part of Lake Victoria: spatial, temporal and bioindicative aspects. Environ. Sci. Pollut. Res, 27, 1485-1498.

Peligro, F. R., Pavlovic, R., \& Rojas, C. (2016). Removal of heavy metals from simulated wastewater by in situ formation of layered double hydroxides, Chem. Eng. J, 306(2016), 1035-1040.

Qiao Qiao, H. I., Guang-Wei, Z. H. U., \& Langdon, A (2007). Bioaccumulation of heavy metals in fishes from Taihu Lake, China. J. Environ. Sci, 19, 1500-1504.

Radu, M., Ionescu, P., Diacu, E., \& Alexandru, A. (2017). Removal of heavy metals from aquatic environments using water hyacinth and water lettuce. Revista de Chimie-Bucharest- Original Edition-. 68. 2765-2767. 10.37358/RC.17.12.5973.

Sayer, C., Máiz-Tomé. L., \& Darwall W. (2018). The importance of freshwater species to livelihoods in the Lake Victoria Basin. In: Freshwater biodiversity in the Lake Victoria Basin: guidance for species conservation, site protection, climate resilience and sustainable livelihoods. IUCN Publication, @inproceedings\{Sayer2018Freshw aterBI. Pp 136-151.

Singh, N., Kaur, M., \& Katnoria. J. K. (2017). Analysis on bioaccumulation of metals in aquatic environment of Beas River Basin: A case study from Kanjli wetland, GeoHealth, 1, 93-105.

Ravindra K. S., \& Bommanna, G. L. (2015). Ganges River Contamination: A Review. Book Chapter. American Chemical Society Publication, Washington, DC. DOI:10.1021/bk-2015-1206.ch008.

Tomno, R. M., Kitulu, L., Nzeve, J. K., Mailu, S., Waswa, 
F., Mailu, S. N., \& Shitanda, D. (2020). Heavy metal contaminants of water, soil and vegetables in Machakos municipality, Kenya. Jour. of Appl. Sci. \& Envir. Manag, 24(12). DOI: 10.4314/jasem.v24i12.3.

Turkmen, N., Sari, F., Poyrazoglu, E., \& Velioglu, Y. (2006). Effect of prolonged heating on antioxidant activity and colour of honey. Food Chemistry, 95, 653657.

Van Dam, A. A., \& Kipkemboi, J. (2016). Sustainable use of papyrus from Lake Victoria, Kenya. In: Finlayson C. et al. (eds). The Wetland Book. Springer, Dordrecht. https://doi.org/10.1007/978-94-007-6172-8 207$\underline{1 .}$

Villa-Achupallas, M., Rosado, D., Aguilar, S., \& GalindoRiaño, M. D. (2018). Water quality in the tropical Andes hotspot: The Yacuambi river (southeastern Ecuador). Science of the Total Environment, 633, 50-58.

Vodyanitskii, Y.N., \& Shoba, S.A. (2015). Biogeochemistry of carbon, iron, and heavy metals in wetlands (analytical review). Soil Sci. Bull, 70(3), 89-97. 